Jorgen Bonde Jensen

\title{
Tiden går og vi går med
}

Et svar på spørgsmålet 'hvor går

litteraturvidenskaben hen'

Tidens ordsprog: tiden går og vi går med. Hvad betyder nu 'vi går med'? Betyder det 'vi følger med' - så godt vi kan? Eller betyder det 'vi forsvinder' med med tiden?

Ordbogens eksempel: engang var der en kejser der med tiden blev munk, afklarer ikke spørgsmålet for mig. Det gør de eksempler jeg selv kan finde på heller ikke: universitetslæreren der i 68 var $68 \mathrm{er}$ og som i 89 føler befrielsen er kommet, befrielsen for 68; forfatteren der var marxist og nu en glødende fortaler for den frie markedsøkonomi, forfatteren der var leninist og som nu beundrer paven, forfatteren der var DKP'er og nu er grundtvigianer, chefredaktøren der var maoist og nu lovpriser kongedømmet, avisen der var til venstre og i knibe og bad chefredaktøren fra højrepressen der havde fremgang om en vurdering af det journalistiske produkt.

Jeg må vist hellere nøjes med foreløblig at konkludere at tiden synes at løbe af med os. Det er også nok. For den der har forestillet sig at gribe ind i tidernes gang, er det en skandale.

Jeg har for nylig læst en bog om sjælevandring! Og i den forbindelse spurgt mig hvad en litteraturforsker kan have været $i$ sin forrige tilværelse. Jeg forstår på bogen at det enten må have været ådselgrib, spyflue, myre eller sjakal, måske måge.

Hovedpersonen i bogen, en litteraturforsker, bliver skældt ud for at være 'ådselæder'. Det er metaforisk ment men behøver jo ikke derfor at være grebet ud af luften. Måske hentyder det til en tidligere tilværelse, som der stadig klæber noget ved ham af, og som måske bl.a. har haft betydning ved hans valg af gerning? Den der skælder ham ud er Pythagoras, der er biperson i bogen men ifølge mit leksikon selv mente at han i sit forrige liv havde været digterguden Apollon selv, og i dette liv var Apollons menneskelige legemliggørelse. Uden at vi vist derfor idag anerkender ham som selve inkarnationen af en digter - ? Meget af det han har skrevet og sagt er vist gået tabt med tiden.

Pythagoras er så at sige grundlæggeren af den vestlige tro på sjælevandring. I bogen er en senere udgave af ham (det må det være) 
tjener for den romerske digter Publius Ovidius Naso, som vi plejer bare at kalde Ovid, og som i bogen går under sit efter- eller tilnavn Naso, 'ham med næsen.' Naso kan gå på så meget udover næsen selv, men det går i hvert fald her på hans lugtesans, hans 'næse' for sammenhængen mellem alt mellem himmel og jord, og så måske også på en tidligere tilværelse som næsehorn? Hans hovedværk er Metamorfoserne og det betyder Forvandlingerne, hvilket allerede antyder afhængighedsforholdet han står i til Pythagoras. Man kan godt spørge sig selv om hovedværket ikke fra begyndelsen er tænkt som én lang naturhistorie der rækker fra stenene til skyerne. Det gør litteraturforskeren $\mathrm{i}$ bogen $\mathrm{i}$ et brev, der aldrig når frem, til Ovids eller Nasos kone. Metamorfoserne er jo ellers den store genfortælling om guderne og heltenes liv, men det vil ikke mindst sige om deres forvandlinger, deres omskabelser, ja deres sjælevandringer fra den ene skikkelse til den anden, fra den ene materie til den anden. Ovid/Naso troede på sjælevandring. Måske havde han også været Pythagoras i en tidligere tilværelse?

Naso skrev helt i overensstemmelse med Pythagoras: "Ingenting bevarer den skikkelse, det har.» Litteraturforskeren læser det og prøver at tyde det. Han var Nasos ven, hans beundrer, hans læser og tilhører, han kom i huset hos ham i Rom. Bogen om litteraturforskeren er bogen om hans eftersøgning af digteren, der er væk sammen med hovedværket Metamorfoserne. På en måde er det Ovid eller Naso der er hovedpersonen selvom han ikke forekommer i bogen men kun er tilstede som skygge for vennen, litteraturforskeren. På en måde er bogen man læser en anden, en senere, nyere udgave af Metamorfoserne. Det er den og det er ikke den. Det er Metamorfoserne alt handler om, men det vil sige at det konstant handler om noget andet.

Bogen jeg læser er skrevet af Christoph Ransmayr. Den hedder Die letzte Welt og det må tydes ikke bare som Den Sidste Verden men som Den Yderste. Betydningen sidst peger muligvis på bekymringen for at

Jergen Bonde Jensen er lektor i nordisk litteratur ved Kobenhavns Universitet.

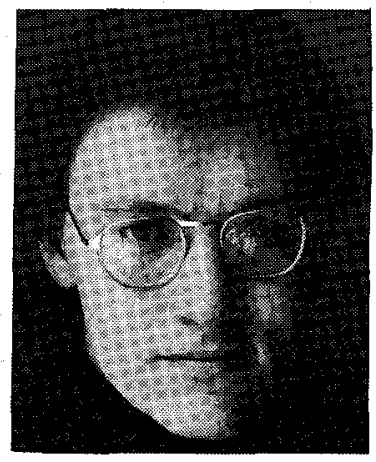


sjælevandringen på jorden kan lide et afbræk, betydningen yderst peger - for så vidt opmuntrende - på at sjælevandringen begynder hvor alt hører op, ved verdens ende, hvor kragerne vender. Dér har du din tekst, litteraturforsker. Dér er omdrejningspunktet, stedet hvor du forgæves holder på formerne og antager nye, hvor din krop bryder sammen $\mathrm{i}$ en anden, og du forsvinder og fortsætter i noget andet, en fugl, måske en sten, uden dermed at finde hvile. Sådan holdt litteraturforskeren af digteren Naso at han opdagede selv stenenes forgængelighed da Naso forsvandt. Men det vil sige deres omsættelighed, til f.eks. luftballoner som en lang næse af en fallos spiller bold med ved et fastelavnsoptog. Den der så det forvandlede menneskes blik i koens åbne øje eller i grisens ivrige blik, den der så rovdyrets lurende blik i øjnene på manden der var fuld, var på pletten, på forvandlingens sted, dvs. kunstens åsted.

Bogen jeg har læst om sjælevandring er en roman. Det er den, men det ville ikke være en moderne roman hvis den ikke fastholdt romanen som den åbne genre og derfor overskred romankonventionen i en eller anden retning. Die letzte Welt overskrider den i to retninger. Fremefter, mod videnskaben og bagud mod epos'et. På den ene side stiller den sig uden for sin genstand og anskuer Naso og hans metamorfoser, herunder dem han selv undergår, i historisk sammenhæng. Kritisk, dissekerende, revolterende mod historiens gang. På den anden side går den ind og op $i$ sin genstand, men det vil sige ind $i$ en forvandlingsprocces, hvor alt bliver muligt - som uvis skæbne. Romanen stemmer sig op mod tidens gang, og den hengiver sig til den i en tone, der er hymnisk. Hvad der kunne synes at være en svaghed og et umoderne træk ved romanen, at den ikke redegør for sin skrifts fiktivitet, dvs. for dens tilblivelse på det fortaltes plan, finder sin begrundelse her, i tilbagefaldet til epos'et og myten. Die letzte Welt er et forsøg på at skrive en mytisk roman. Men myten er den fortælling der intet ophav (ingen autor) har.

Romanens hovedperson er en historisk person, der hedder Cotta. Han rejser til verdens ende for at bedrive sin litteraturforskning. Eller skulle vi istedet tale om litteratursøgning? Verdens ende ligger ved Sortehavet. Sådan tager det sig ud, set fra metropolen Rom. Rigets grænser strækker sig til Sortehavsegnene. Byen Tomi, alias Constanta i det nuværende Rumænien, hører under riget, men heller ikke mer. Byen lever så at sige på kanten af loven, kaldet romerretten (og på kanten af menneskerettighederne, ville vi tilføje $\mathrm{i}$ dag). For 9 år siden blev Ovid med næsen forvist fra Rom til Tomi. Nu er rygtet om hans død nået frem fra exilet til metropolen. Cotta går i Nasos fodspor for at fastslå eller afkræfte rygtet og redde værket, Metamorfoserne. 
Naso brændte det $\mathrm{i}$ bitterhed inden han rejste. Måske har han genskabt det i sit exil? Selvom han ikke har, vil Cotta bemagtige sig det »og lægge det tilbage i hænderne på Rom.« Hvordan det så skal ske. Ligesom man taler om opsøgende journalistik, må man nok sige at det her drejer sig om opsøgende litteraturforskning. Hvis man kan forestille sig sådan noget. Betegnelsen litteraturforskning om det Cotta foretager sig er i øvrigt min, må jeg nok understrege. Jeg kan ikke finde på noget bedre at kalde det, men kan godt se at man kunne kalde det noget andet. Bogen selv siger ikke at Cotta er litteraturforsker men blot at han er 'en af mange'. Han er en af dem, hedder det, der under kejser Augustus søger bort fra det stærkt regulerede liv i Rom, fra overvågningen, hele magtapparatet, faneskovene, parolerne, rekrutteringen til hæren, den åndelige mobilisering, altså søger et liv uden opsyn, i større frihed, ved imperiets grænser. Han har med andre ord flere grunde til at rejse, også det der i et moderne asyllands afværgesprog kaldes bekvemmelighedsgrunde. Motiverne er ikke specielt ædle. Han rejser indrømmet for at høste anerkendelse for at genopdage en stor poesi. Et andet, tredje eller fjerde motiv er at han simpelthen keder sig i Rom. Hvormed vi turde været kommet langt bort fra litteraturvidenskaben og dens dyrkere og deres motiver. Ikke også?

Cotta er også en af de mange, erfarer vi, for så vidt han et sted i sig selv støder på sin egen romerske kropskulturs grænser. I selskab med en ung kvinde han interviewer i Tomi om Naso, blir han rå. Kvinden har kendt Naso, og Cotta vinder den fåmælte piges fortrolighed og får hende til at fortælle. Han lytter opmærksomt til hende. Og opmærksomheden, det at holde fangen og blive holdt fangen, viser sig at være atmosfæren, det erotiske begær vokser frem af. I stilheden efter det hun siger om Naso, i nattens frembrud, hvor ansigter blir til skygger, og kroppene til omrids, og enhver blir sig sin ensomhed bevidst, vil han bemægtige sig hendes krop, fyldes af den og fylde den ud. Og hengiver sig $\mathrm{i}$ troen på at hun lige så beredvilligt åbner sin favn for ham som sin mund. Han trækker hende ind til sig for at trække hende ind under sig, og viser sig 'som en af mange.' En af de mange 'litteraturforskere', der forveksler pigens grønne kåbe med pigen selv, skinnet med virkeligheden, skyen med Juno, og ikke ved, endnu ikke har lært, at i litteraturen favner man skyen eller begår voldtægt. Cotta søger Naso. Pigen han taler med hedder Ekko. Hun er et ekko af Naso. Hans tilnærmelse til pigen og hendes afvisning af ham, er hans tilnærmelse til Naso som mand og hans tilnærmelse til litteraturen, der $i$ Nasos fravær vil have ham til at se ikke bare betingelsen for sin egen eksistens men for altings fortsættelse. Hvad tåler tiden, forstået 
som din tid, som vores tid, til hver en tid dårligere end fraveret, og det der ækvivalerer fraværet: stilheden, tavsheden, det tomme rum, de blege farver? Det blir værre og værre.

Efter voldtægten rører han hende ikke igen. Selvom de fortsætter med at ses og tale sammen. Det eneste der er mellem dem på deres ture gennem den stenede egn om Tomi er Naso, Nasos beretninger og beretningerne om Naso.

Hvorfor blev Naso og Metamorfoserne forstødt til den fjerneste krog af riget? Svaret ligger $\mathrm{i}$ hovedværkets titel når man sammenholder den med samfundstilstanden i Rom, dvs. med det augustæiske diktatur og dets iboende angst for forandringer. Det fortælles at Augustus havde et næsehorn i sit våben. I en scene kort før Nasos landsforvisning møder vi kejseren tankefuld ved vinduet, hvor han kigger ned på et næsehorn $\mathrm{i}$ sin have. Dyret befinder sig i en pøl, der er indhegnet af et palisadeværk. Dyret gør forsøg på at komme fri og har i sine forgæves forsøg afbarket træværket. Dyret er plaget af fluer og stikfluer. Det kaster et par gange om dagen mudder over sig og vælter sig i sølet for at blive fri for sine plageånder og varmen. Når kagerne af mudder tørrer ind på kroppen og går af i flager, overfaldes dyret i 'sårene' af sine plageånder med fornyet ekstra styrke, som om de siger: nu skal du få. Irriteret afgør kejseren kort efter i en hảndevendning hvad han mener der skal ske med Naso. Han drejer faktisk bare hånden som når man ryster en flue af sig. Embedsmænd udlægger tegnet sådan at det må være meningen at Naso, bymennesket, skal ud af Rom i landflygtighed, m.a.o. ud af sin beskyttelsesskal af civiliseret mudder. Flås. Som Marsyas, som den satyr han var. Som den hvis rå fløjtespil generede den instituerede (apollinske) opfattelse af ordentlig kunst. Naso er en irriterende flue $i$ en større sammenhæng, der når man fjerner den bare viser sig at være huden selv på samfundets egen næse. Man lemlæster Naso ved at fjerne ham fra Rom. Men man lemlæster samtidig Rom. Næsehornet er kraftens billede, den er det lave som den ophøjedes navn, Augustus, suger sin legitimitet af. I billedet af det plagede indespærrede dyr er næsehornet kraften, som diktaturet ikke tør slippe fri. I skikkelse af Naso, digteren, er den det, der helt lukkes ude fra Rom, og efterlader næsehornet som en tykhud, et insignie, et billede uden hold i virkeligheden.

Ransmayr forestiller sig at det der gir stødet til landsforvisningen er et optrin på det nye kæmpestadion i Rom som Augustus lod bygge. En af de officielle indvielsestalere skal erstattes af Naso, og i nærværelse at Augustus holder Naso så en tale om sport og cirkus som en gryde hvori de forsamlede titusinder af mennesker skal koges til en 
grød af myrer der for altid skal være til at styre. Det var anledningen der pegede på årsagen: Nasos appel til folkets frihedstrang. Den der gennemsyrer hans egen digtning. Var det ikke, spørges der, Naso, »der med sine fortællinger og dramer havde rørt ved det glemte og erindret Rom, der var stivnet til stat, om arkaiske, ubændige lidenskaber?«

Et fastelavnsoptog i Tomi ved Sortehavet blir til tegn på at Naso i det fremmede fandt en ny hud at krybe i. Cotta indser at indbyggerne $i$ byen er kommet til at stå Naso nærmere end man skulle tro når man spør dem ud om ham og bare støder på deres tavshed. Beboernes optog blir til bevis (blandt andre) på at Naso har taget skikkelserne i sin poesi med sig i landflygtigheden og arbejdet videre med dem, med forestillingen om dem, dvs. med forestillingen om forvandlingen, in casu deres omplantning til de fjerne ugæstmilde egne i bjergene ved havet. Han havde vævet videre på sine fortællinger. Hvordan ellers forklare den kendsgerning at slagteren i det hul Tomi er kommet på den idé til fastelavn at manifestere de skjulte sider af sig selv i skikkelse af solguden Apollon?

Slagteren, jf. hans håndværk, drømmer åbenbart om at råde frit over liv og død, om almagt. Han har som husherre i sit virkelige liv voldtaget $\sin$ kones søster og skåret tungen ud på hende så hun ikke har kunnet anklage ham for noget. Han har skubbet hende ud af sit hus, ud over afgrunden i bjergene, hvor han forbrød sig mod hende. Hans navn er Tereus, hans svigerindes navn Philomela. De lever op til deres navne, kan man sige, til hvad der i forvejen er sagt om dem i myten, og sagt om hvad der videre skal ske. Slagterens kone lever, da sandheden, dvs. Philomela, kommer for en dag, op til sin del af myten og slår sin og slagterens søn ihjel. Slagteren vil i sin tur hævne drabet på sønnen og slå konen og Philomela ihjel. Og de to søstre der har gemt sig i Cottas hus (som han kun har lejet sig ind i og først lidt senere overtager som sit eget) undslipper ligeledes (som i myten) den rasende ægtemand og voldtægtsmand ved at forvandle sig til en nattergal og en svale og flyve ud gennem den knuste, åbne rude i Cottas hus. Som i myten, - der ikke bare binder, men befrir.

Det der i Rom stivner og forstener til mindemærker, rytterstatuer, relieffer og tempelfriser, som mosset kryber henover, er i Tomi; viser det sig, "vildt og levende« som "urtidsnæsehornet" $i$ imperatorens have.

Der var et selvbesindelsens øjeblik, en chance for at vende om, gå i sig selv igen, dvs. forandre sig, og kalde Naso hjem. Det var da Augustus døde og Naso havde været 7 år i Tomi. Håbet sluktes da Augustus' efterfølger Nero også lod sig ophøje og dyrke som gud, dvs. 
som den, der som tiden går, ikke går med, men er evig og uforanderlig den samme. Naso havde forudset katastrofen og dermed sin egen uafvendelige skæbne. I alt hvad han havde gjort og sagt havde han forudsagt magtens uundgåelige forvandling til afmagt, styrkens forstening, stenens forvitring. Det var derfor han var forvist og ikke måtte komme igen.

Ekko fortæller om katastrofen, at Naso spåede at en stormflod ville overskylle jorden $\mathrm{i}$ hundrede år og skylle alt liv væk som hud fra en krop, som jord fra en sten. Hendes beretning er som et ekko af noget der er sket, så virkeligt, så nærværende, vil jeg som læser tilføje, forekommer det at være.

Naso spåede at de nye mennesker der ville opstå af stormfloden ville være af sten, med øjne af sten som statuerne i Rom, uden sprog for kærlighed, - eller for had, uden følelser, uden medfølelse, med hjerter af basalt.

Hvorfor skulle det dog gå sådan? Fordi man i Rom, i metropolen, hvor verden regeres fra, ikke vil se forsteningen $\mathrm{i}$ øjnene som vilkåret for sit eget liv, som indledningen til den død der er forvandlingens nåleøje, og som man skal igennem i levende live for ikke bare at lukke for livet men åbne for det - idet man går. Det er det svære, som selv litteraturforskeren på betryggende afstand af det hele og sig selv har svært ved at forstå. Er det nu også rigtigt, og hvad vil det nærmere sige? Hvad skulle vi være bange for? For rædslen ved enhver mindelse om forvandlingen, om grænserne altså vi har overskredet bagude og skal overskride fremefter. Cotta, litteraturforskeren, opdager under samlejet med Ekko en skjold på hendes ryg. Den fylder ham med væmmelse. Det er et hudløst sted, et sted hvorfra hun i et væk kaster ham. Det er herfra hendes løse hud og mange skæl kommer. Det er en plamage der som et dyr flytter sig over hendes krop. Det er en fortidsøgle, der viser indad $i$ hende, og bagud $i$ hendes tilværelse (tilværelser) mod fjerne tider, hvor den tiltrækkende kvindekrop var ét med det skællede, slimede uhyre. Det er det hun er et ekko af.

Hvad var det der drog selv Naso mod masserne, successen og populariteten. Var det ikke svage øjeblikkes drøm om et evigt liv $\mathrm{i}$ dette? Var rehabiliteringens 'første marmor-tegn' efter hans død, hvormed styret tog ham til indtægt for sig, ikke tegn på noget der allerede var på færde i hans eget liv? Selvfølgelig. Litteraturforskeren er ikke desto mindre overtydet om at Naso i Tomi fik fortalt sine historier til ende, set enden på sine personers liv, og på den måde befriet sine historier for dem og deres orden. Naso har i tide set sig selv som kiselsten, som skarv, og som skurv på den sidste forsvindende murrest af en by. Vidst at virkeligheden var til uden hans hjælp, at hans 
optegnelsers opgave ikke var at opfinde virkeligheden, og at de for så vidt var overflødige.

For litteraturforskeren er der endnu en optegnelse tilbage at tolke. Det er hans eget navn, hans plads i sammenhængen. Navnet er fremmed og hjemligt, en hud og en frakke, navnet Cotta er tilfældigvis både et romersk mandsnavn og et tysk stednavn. Hvad betyder det? Kogt i den sorte gryde i Rom? Brændt i Nasos ild - til sten? Cotta slynger i de sidste linjer af Ransmayrs bog sit navn mod klippesiderne uden for Tomi. Idet navnets genlyd når hans ører svarer han HER! Det der slår tilbage i dette $e k k o$ er hans eget navn. Smukt: når hun i hans erindring siger hans navn er han indføjet i den dybere mening med sig selv. Her ligger forståelsen af meningen med og accepten af vilkåret for al litteratursøgning - og oprøret mod vilkåret. Det minder om en filmforevisning i Tomi i begyndelsen af litteraturforskerens ophold $\mathrm{i}$ byen. På film var der én der ville forlade sin elskede for at drage til Delphi og spørge guden, Apollon, til råds om noget. Han druknede i stormen. Men i stormen, til sidst, vidste han at svaret på hans spørgsmål lå $i$ hans elskedes arme.

Det er alt sammen sagt for. Blot samlet her påny. Som man ser også i den forstand at tiderne falder sammen, og landene og landskaberne. Der er ingen bjerge, ingen stenmassiver ved Tomi. Olympen ligger i Grækenland og ikke ved Tomi. Men i Den sidste Verden ligger den her. Som Bøhmen ligger ved havet i Shakespeare's Vintereventyr, i Ingeborg Bachmanns digt "Böhmen am Meer«, og Hans Magnus Enzensbergers Europa-bog. Det kunne bogen havde heddet: Bøhmen ved havet. Eller Østrig ved havet. Kun en bjergbo kunne indføre os som Ransmayr gør i stenenes liv. Stenenes bog var en tredje mulig titel for bogen. Sådan skulle Metamorfoserne have heddet, ifølge Den sidste Verden.

Hvor bliver Historien af? Som pointe udebliver den, og skal den udeblive. Men udebliver den ikke dermed overhovedet $i$ alle tiders mytologiske bog? Blir alt ikke til skæbne og blind gentagelse. Er der andet at gøre end at føje os - efter den sidste verden? Hvad siger ikke Pythagoras? Engang drømte han om tidens kraft, der skulle undergrave menneskets magt over mennesker og forvandle magten til et muntert fællesskab. »Men brevene, aviserne, der nåede ham i årenes løb, dementerede ham." Det er situationen, vi befinder os i lige nu. Men er det også situationen vi skal acceptere som den endelige?

Nej, Pythagoras husker, hos Ransmayr, om sig selv også at han i sit tidligere liv har været ogle og officer. Ingen snak om Apollon og gudens legemliggørelse. Øgle og officer peger på en berøring med fornærmende former for liv og død, med livet som skæl og med døden som 
livsberøvelse. Pythagoras drømmer ikke mere om at herske over liv og død. Han har, hos Ransmayr, lod og del i dem. Heri kan man se et fremskridt $i$ erkendelse, for litteraturen, og det liv den evt. handler om.

Rom er »nødvendighedens rige. « Friheden findes ikke, heller ikke i denne bog, adskilt fra det. Kun idet Pythagoras, Naso og hans fortolker erkender det og ser deres egen undergang som filosof, digter og litteraturfortolker åbent $\mathrm{i}$ øjnene, kan de håbe og tro på - genopstandelsen, i en eller anden form.

Hvad litteraturforskeren er i et kommende liv har jeg ikke haft mod til at spørge mig om endnu. Svaret findes givetvis allerede, og skal blot forskes frem. Hvad enten vi følger med eller forsvinder, så forsvinder vi - og følger med, dvs. under alle omstændigheder så fortsætter vi da - med noget andet- selvom vi måske ikke er rigtig klare over det. Hvis vi skal tro Ransmayr og hans bog.

Februar 89

Kilde: Christoph Ransmayr: Die letzte Welt. Roman. Med et sammenlignende »Ovid-repertoire« på $2 \dot{8}$ sider over skikkelser hos Ovid og hos Ransmayr. Og med ciffertegninger af Anita Albus. Udkommet i Die andere Bibliothek, udg. af Hans Magnus Enzensberger. Greno Verlag, Nördligen 1988. 323 sider.

Der henvises som følger til Ransmayr: s.32: til s.17; s.33: 198, 15; s.34: 111 ; s.35: 172, 125, 150, 147; s.37: 93 , 94; s.38: 146, 287; s.39: 251; s.40: 287. 